\title{
Relation among Aromatase P450 and Tumoral Growth in Human Prolactinomas
}

\author{
María José García-Barrado 1,2,*, Enrique J. Blanco 2,3, María Carmen Iglesias-Osma 1,2 (iD, \\ Marta Carretero-Hernández ${ }^{3}$, Leonardo Catalano-Iniesta ${ }^{2,3}$, Virginia Sanchez-Robledo 1,2, \\ Manuel Carretero ${ }^{4}$, Julio Joaquín Herrero ${ }^{5}$, Sixto Carrero ${ }^{5}$ and José Carretero ${ }^{2,3}$ \\ 1 Department of Physiology and Pharmacology, Faculty of Medicine, University of Salamanca, \\ 37007 Salamanca, Spain; mcio@usal.es (M.C.I.-O.); robledo@usal.es (V.S.-R.) \\ 2 Laboratory of Neuroendocrinology, INCyL and IBSAL, University of Salamanca, 37007 Salamanca, Spain; \\ ejbb@usal.es (E.J.B.); leonardo.catalano@usal.es (L.C.-I.); jcar@usal.es (J.C.) \\ 3 Department of Human Anatomy and Histology, Faculty of Medicine, University of Salamanca, \\ 37007 Salamanca, Spain; martataes@gmail.com \\ 4 Faculty of Human and Social Sciences, Pontifical University of Salamanca, 37002 Salamanca, Spain; \\ mcarreterogo@upsa.es \\ 5 Department of Surgery, Faculty of Medicine, University of Salamanca, 37007 Salamanca, Spain; \\ jhpayo@usal.es (J.J.H.); scarrero55@gmail.com (S.C.) \\ * Correspondence: barrado@usal.es
}

Received: 15 September 2017; Accepted: 27 October 2017; Published: 1 November 2017

\begin{abstract}
The pituitary gland is part of hypothalamic-pituitary-gonadal axis, which controls development, reproduction, and aging in humans and animals. In addition, the pituitary gland is regulated mainly by hormones and neurotransmitters released from the hypothalamus and by systemic hormones secreted by target glands. Aromatase P450, the enzyme responsible for the catabolization of aromatizable androgens to estrogens, is expressed in different parts of body, including the pituitary gland. Moreover, aromatase P450 is involved in sexual dimorphism where alteration in the level of aromatase can initiate a number of diseases in both genders. On the other hand, the direct actions of estrogens, mainly estradiol, are well known for stimulating prolactin release. Numerous studies have shown that changes in the levels of estrogens, among other factors, have been implicated in the genesis and development of prolactinoma. The pituitary gland can produce estradiol locally in several types of endocrine cells, and it is possible that aromatase could be responsible for the maintenance of the population of lactotroph cells and the modulation of the action of central or peripheral regulators. Aromatase overexpression due to inappropriate gene regulation has clinical effects such as the pathogenesis of prolactinomas. The present study reports on the synthesis of pituitary aromatase, its regulation by gonadal steroids, and the physiological roles of aromatase on pituitary endocrine cells. The involvement of aromatase in the pathogenesis of pituitary tumors, mainly prolactinomas, through the auto-paracrine production of estradiol is reviewed.
\end{abstract}

Keywords: pituitary gland; aromatase; prolactinoma

\section{Introduction}

Aromatase P450 is a complex protein belonging to family 19 of the P450 superfamily of enzymes, termed CYP19. It is found throughout the phylum vertebrates and formed by two components, cytochrome P450 and nicotinamide adenine dinucleotide phosphate (NADPH) cytochrome P450 reductase, located in the membranes of the endoplasmic reticulum; although the human gene is unique compared to the rest of the other members of this superfamily [1,2]. In mammalian systems, Cyp19 uses C19 androgens as their substrate and enzymatically removes C19 to form a phenolic A-ring in 
the steroid. Depending on which androgens are attached to the prosthetic groups, the products of androstenedione, testosterone, or 16-OH-androstenedione, are estrone, estradiol, or estriol, respectively. The estrogens formed inside the cell interact with estrogen receptors, triggering alterations in gene expression and in cellular functions [2-5]. Hence, steroids are implicated in many biological processes including development, hypothalamic programming, sexual differentiation, reproductive physiology, behavior, osmoregulation, metabolism, regulation of the hypothalamic-pituitary-gonadal axis, and hypothalamic-pituitary-adrenal axis [6].

Aromatase is extremely critical as an estrogen biosynthetic enzyme. Physiologically, it participates in functions such as glucose homeostasis, lipid homeostasis, brain function, follicular growth, bone mineralization, epiphyseal closure, and the coordination of the ovulatory process [7], and has also been found to be directly responsible for sexual dimorphism in the nervous system. Its expression and activity varies in different parts of the body, and is highly active near gonads, adipose tissues, skin, bone, brain, adrenal gland, liver, placenta, breasts, and hair follicles. It is known to be involved in tumorigenesis and alterations in the level of aromatase can initiate a number of diseases in both genders [2,8-12].

The conversion of androgen to estrogen by aromatase has two effects: on one hand it produces an estrogen molecule and on the other it removes the androgen molecule. Although the amount of estrogens synthesized by this way is quantitatively small, even less than $1 \%$, it should be emphasized that in terms of potency the hormonal activity of estrogens can be up to 1000 times greater that of the androgens [1]. The amino acid sequence of aromatase P450 was described by Hickey and co-workers [13]. This sequence results from the transcription and later translation of the aromatase CYP 19 gene. Different isoforms of aromatase P450 have been reported [14]. These partially differ in the carboxy-terminal amino acid sequence, which could account for some of the differences observed by different authors in the tissue distribution of the enzyme.

Pituitary adenomas are a diverse group of tumors arising from adenohypophyseal cells in the pituitary gland. The proportion of adenomas associated with hormonal hypersecretion or showing further progress is currently unknown. In general, the data on the prevalence of pituitary adenomas are based on anatomical studies with results extracted from either serial autopsies or from magnetic resonance imaging and suggest that the overall estimated prevalence is of $16.7 \%$ of all brain tumors [15]. However, local surveys published in Belgium [16] and the UK [17] propose that the prevalence of pituitary adenomas has risen fourfold over the last decades as detected by the better screening of these populations. Although they are considered benign, pituitary adenomas are the cause of significant morbidity due to increased hormone secretion and to a possible compression of neighboring structures [18-21].

Prolactin-secreting pituitary tumors are called prolactinomas and are highly prevalent along with non-functioning pituitary tumors [22,23]. Their frequency varies with age and sex, being more common in 20- and 50-year-old women than in men; however, later on the frequency of prolactinomas is similar in both sexes [24]. One possible explanation for the increased prevalence of prolactinomas in women may be related to the fact that clinical presentation in women is more evident, usually the classical amenorrhea-galactorrhea syndrome, whereas men may ignore the symptoms of impotence and decreased libido and the diagnosis is often made when signs of compression due to the tumor develop [22].

Additionally, some patients with acromegaly are carriers of mixed adenomas, secreting growth hormone and prolactin [25]. The initiation, development, and progression of adenomas is not well known. However, many factors may influence the proliferation of prolactinomas, such as angiogenesis, apoptosis, growth factors, oncogenes, tumor suppressor genes, and hormone receptors [26]. Studies in animals and humans have demonstrated that estrogen stimulates pituitary tumor transforming gene (PTTG) expression [27]. This gene, the first proto-oncogene to be identified, is weakly expressed in normal tissues. However, it is widely detected in malignant cell lines and in most pituitary tumors [28,29]; thus, estrogens are one of the factors involved in the pathogenesis of prolactinoma. 
Recently, after a systematic review, a large number of candidate genes thought to contribute to tumorigenesis, invasion, recurrence, and hormonal hypersecretion in prolactinomas have been revealed [23]. Of the over-expressed genes identified, HMGA2, HST, and SNAP25 showed a clear association with prolactin hypersecretion and tumor formation. The under-expressed genes UGT2B7, Let7, and miR-493 are primarily involved with steroid metabolism and cell cycle regulation, which may contribute directly to the formation and progression of prolactinomas [23].

\section{Aromatase Expression in Pituitary Gland}

The pituitary is an endocrine gland that is affected by the secretion of gonadal steroids and is involved in sexual differences that appear in life. The possibility that aromatase might be produced in this organ and might exert its action at a local level is of particular relevance to this study.

In previous work deadling, with humans and rodents with normal or tumoral pituitaries, we have described the immunohistochemical expression of aromatase in the pituitary gland $[8,30,31]$. Similar findings were confirmed later on in animal species and different brain structures [32-37]. The role played by the transformation of testosterone into estradiol with respect to the secretion of the gland, remains to be fully elucidated. Although it could be debated whether the observations reported in different studies might be developed in the hypothalamus, in the pituitary gland or in both at the same time, such as the fact that the administration of aromatase inhibitors increases circulating luteinizing hormone ( $\mathrm{LH}$ ) levels [38], there is evidence that suggests pituitary aromatase has a potential physiological or pathophysiological importance [9].

We have demonstrated [31], by means of immunohistochemistry, that aromatase is expressed in the rat pituitary gland as early as Day 17 of prenatal development, the cells positive for the enzyme being more prominent and numerous at Day 19 up to birth. Postnatally, towards puberty (around 21 days), differences between males and females begin to appear. Thus, the immunohistochemical expression of aromatase P450 in the adult rat pituitary gland is sexually dimorphic. Finally, non-tumoral pituitary from male and female aged rats hardly express the enzyme [39]. By means of immunohistochemistry, Western blotting, and in situ hybridization, it has been demonstrated that gonadal steroids play an important role in the expression of aromatase in the pituitary gland of adult rats. Moreover, treatment with aromatase inhibitors induces morphometric alterations and changes in the cellular proliferation of some glandular pituitary cells and similar changes can be observed in lactotroph cells or LH-positive gonadotroph cells in knock-out mice for aromatase [40,41].

Although the above findings are suggestive of a defined role for pituitary aromatase, the immunohistochemical expression of the enzyme might not be related to a biological action at the pituitary level. However, the observation of the strong correlation of immunocytochemical expression in the same glandular cell for aromatase and estrogen-receptor $\alpha$ suggests that the enzyme would exert a pituitary auto-paracrine effect, as is discussed in the review of Carretero and co-workers [42].

\section{Estrogens, Prolactin and Aromatase}

The relationship between estrogens, in particular estradiol, and prolactin have been well known for some time. The direct actions of estrogens stimulating prolactin release are well documented in the literature [43-45]. In fact, estradiol is an important regulator of prolactin synthesis [46]. The pituitary lactotroph cells have an estrogenic receptor (ER), and there are estrogen-responsive cells [47,48]. Estrogens regulate transcription of the rat prolactin (PRL) gene in vivo [49] through at least two independent mechanisms [50,51] that culminate with an increase in prolactin mRNA levels [46] and that upregulate genes such as vascular endothelial growth factor (VEGF), transforming growth factor $\beta$ (TGF $\beta$ ), and galanin [49-52]. Estrogen stimulate the pituitary vasoactive intestinal polypeptide (VIP)-producing cells and it is a peptide that, in an auto-paracrine way, stimulates prolactin and lactotroph cells [53].

The estrogen-treated rats are an interesting and well-studied model of pituitary hyperplasia. The chronic treatment with estradiol elicits, in a first phase, clear signs of hyperactivity and hyperplasia 
in lactotroph cells $[54,55]$, hyperprolactinemia and reduction dopaminergic action at the pituitary level. Ovariectomized and ER $\alpha$-knockout animals have a significant reduction in pituitary PRL levels and the number of lactotrophs cells, suggesting a requirement of estrogen for normal lactotroph function [52]. After the administration of estradiol to adult male rats, lactotroph cells acquire secretory properties and morphological characteristics similar to those found in females, with larger cells that have hypertrophy of the Golgi apparatus, rough endoplasmic reticulum including Nebenkern images, and increases in exocitosis [56,57]. Moreover, estrogens modulate the transdifferentiation of pituitary prolactin and GH cells [58]. In addition, other factors may be involved in these processes, such as interleukins [30,59], dopamine [60,61], and thyrotropin-releasing hormone (TRH) [62,63].

The genomic and non-genomic effects of estrogens have also been reported, using rat pituitary-derived cell lines such as GH3 $[64,65]$. The GH3 cell line, one of the models developed to study prolactinomas in vitro, was generated by treating a rat with high doses of estrogens, in which a prolactinoma developed [6].

Estradiol is known to rapidly activate many signaling molecules, including insulin-like growth factor 1 receptor (IGF-IR), epidermal growth factor receptor (EGFR), and mitogen-activated protein kinase (MAPK) in breast cancer cells. Blockade of estradiol synthesis with aromatase inhibitors or antagonism of its action with anti-estrogens represents first-line treatments for patients with estrogen-receptor-positive breast cancer [66].

The epidermal growth factor receptor (EGFR, ErbB, and HER) family comprises four subtypes of families that are associated with transmembrane tyrosine kinase receptors. EGFR and HER2 are expressed in normal anterior pituitary cells, including lactotrophs cells and induce prolactin release. Moreover, EGFR/HER2 signaling regulates tumor growth and hormone production in lactotroph tumors among others [67]. In EGFR- and HER2-overexpression transgenic models larger tumors appear that respond to tyrosine kinase inhibitors [68]. Although the relation among aromatase, estrogens, and EGFR have been studied in different tumors such as breast [69], endometrial [70], lung [71], and liver [72] tumors, among others, the relationship between EGFR and aromatase in pituitary gland or prolactinomas has not been well analyzed to date, but its participation should not be ruled out.

Pituitary aromatase is produced in different cell types, including normal and tumoral lactotroph cells $[8,35]$. This is of particular relevance since the transformation of aromatizable androgens into estradiol means that, in males the androgenic inhibitory effect on prolactin is transformed, locally and/or intracellularly, into a stimulatory effect, allowing the population of lactotroph cells to be high in this sex. The treatment of male rats with aromatase inhibitors elicits a decrease in the activity and proliferation of lactotroph cells [41], and similar findings can be observed in aromatase knock out (KO) mice [73].

\section{Possible Involvement of Aromatase P450 in the Pathogenesis of Prolactinomas}

As described above, estrogen synthesis is a process that does not necessarily derive from peripheral sources but can be synthesized de novo in different tissues [74] from testosterone by the action of aromatase $[1,2,41]$. Chronic treatment with estradiol induces, in a first phase, cell hyperplasia prolactin, constituting, in a second phase, prolactinoma, depending on the duration of treatment [75]. In the same manner, numerous studies have shown that supraphysiological levels of estrogens, among other factors, have been implicated in the genesis and development of prolactinomas and VIPomas $[25,27,29,76,77]$. Thus, if one of the factors that has been implicated in the genesis of prolactinomas is the estradiol, because the tumor develops following chronic treatment with the steroid, and the pituitary produces estradiol by acting of aromatase, it is not unreasonable to consider the possibility that the development of pituitary tumors, and in particular the development of prolactinomas, could be related to the local production of estradiol from testosterone through the action of aromatase (see Figure 1).

Although mutations or polymorphisms of the CYP19 have been described and their participation on the regulation of postmenopausal circulating sex hormones [78] or in the development and 
prognosis of breast cancer [79], there is no evidence of genetic variations and the regulation of pituitary prolactin secretion or the development and growth of prolactinomas.

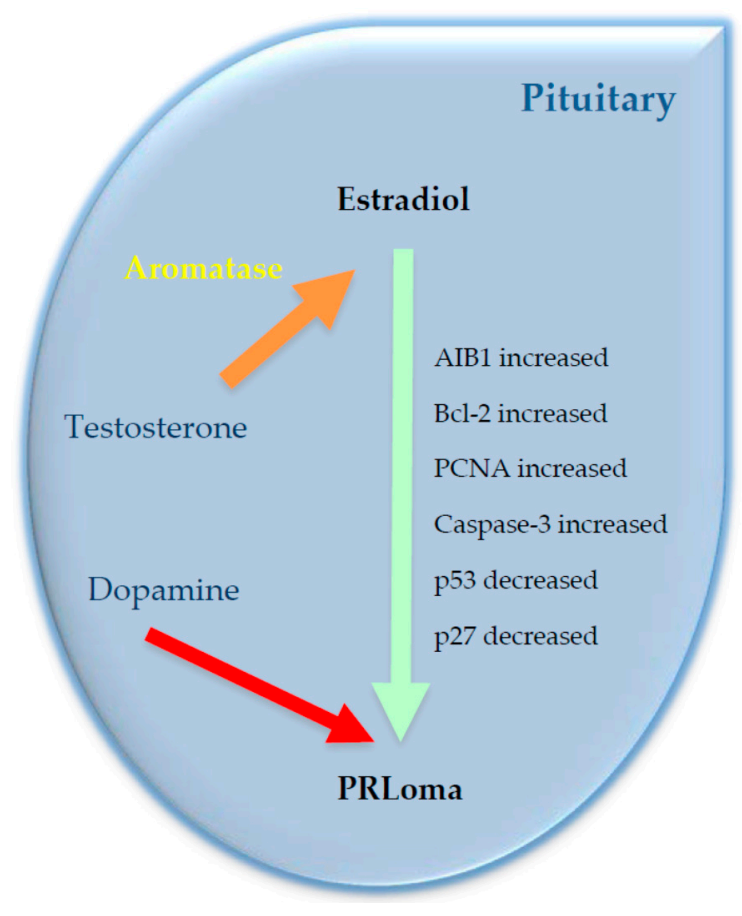

Figure 1. Schematic diagram of the relation among aromatase P450 and growth markers in prolactinomas. Dopamine and steroids are regulators of prolactin production. Dopamine suppresses the prolactin release (red arrow: inhibition), while estradiol is an important regulator of prolactin synthesis (blue arrow: stimulation). The conversion of testosterone to estradiol is mediated by aromatase (orange arrow: stimulation). When some markers present inadequate regulation or their intracellular localization altered, they can lead to an overexpression of aromatase and trigger prolactinomas. In prolactinoma, AIB1, Bcl-2, and proliferating cell nuclear antigen (PCNA) markers are increased and Caspase-3 p53 and p27 are decreased (Modified of [73]).

In our laboratory, evidence has been found suggesting an important relationship between the pathogenesis of prolactinomas and the overexpression of aromatase in the pituitary gland of rodents and humans. For this reason, two series, one of 105 adenomas obtained from female Sprague-Dawley rats of 24 months of age [10] and the other of 87 spontaneous adenomas from women between 23 and 67 years old obtained from surgical treatment were analyzed [42]. In both cases, immunoreactivity to the enzyme appeared in endothelial cells and glandular cells. Akinci et al. [80] have detected the presence of aromatase levels higher in patients with prolactinoma than normal pituitary tissues. Although no difference was found between men and women, aromatase expression was shown to be higher in men with an invasive adenoma than in those without invasive adenoma. Similarly, the association among aromatase and pituitary tumors has been described in both, men and women [12,81]. The importance of the involvement of aromatase in the development of prolactinomas is seen upon observing that mice $\mathrm{KO}$ for aromatase do not develop prolactinomas [73].

Contrary to what occurs for breast tumors, there are only a few studies analyzing the clinical relevance of aromatase in prolactinomas, and the use of aromatase inhibitors is useful in the restoration of gonadal function by testosterone in men with prolactinomas [81-84].

\section{Balance among Cell Proliferation and Apoptosis in Prolactinomas}

The maintenance of tissue homeostasis in the anterior pituitary gland results from a balance between cell proliferation and death by mechanisms that are tightly regulated. Classically, 
the proliferative cell fraction in the anterior pituitary of adult animals is described as low, while it is high during development $[85,86]$. The effects of estrogens on the pituitary gland are not only those that are classically described as mitogenic, but anti-proliferative and pro-apoptotic actions are also apparent [87].

After extensive studies were carried out regarding changes in proliferation and apoptosis in pituitary tumors, higher apoptotic activity pituitary carcinomas compared with adenomas was observed, indicating that apoptosis could be a useful prognostic marker [88]. However, other authors found that apoptotic indices were not predictive of the growth rate of non-functioning pituitary tumors $[89,90]$. These discrepancies may be due to the technique used to detect apoptotic cells in each study. Kontogoergos et al. [88] showed that functioning adenomas had higher indices than did non-functioning tumors, although the highest apoptotic indices were observed in corticotrope adenomas, and in untreated adenomas, particularly prolactinomas.

The expression of Bcl2 and Bcl-2-like protein 4 (BAX), respectively, has been used as anti-apoptotic and pro-apoptotic factors. In non-functioning adenomas as well as in PRL-secreting adenomas the expression of Bcl-2 found decreased [80] and BAX protein was increased when associated with pituitary tumor progression. In female rats, estrogens induce changes in the balance of pro- and antiapoptotic $\mathrm{Bcl}-2$ family proteins (Bcl-2 and $\mathrm{BAX})$ and inhibition of the nuclear factor kappa-light-chain-enhancer of activated B cells (NFkB) pathway [91,92]. In the male, 17 $\beta$-estradiol exerts rapid apoptotic action in lactotropes, somatotropes, or gonadotropes cells of pituitary gland. However, the effects of gonadal steroids on the expression of Bcl-2 and BAX, in the anterior pituitary gland of male rats, have not been modified [93].

Previous findings from our laboratory show that the expression of pituitary aromatase was higher in male than in female rats [31], and aromatase expression in lactotropes is negatively correlated with age and almost completely disappears in the pituitary gland of aged male rats [39]. Therefore, aromatase can locally generate high levels of estradiol that can act through auto-paracrine mechanisms $[7,36]$. The in vitro and in vivo expression of aromatase is in the lactotroph cell of male rats and is involved in the control of proliferation and prolactin release by transforming testosterone to estradiol [41]. Moreover, the pituitary aromatase activity could be involved in the regulation of the apoptosis of pituitary cells [93]. Other studies have shown that, in patients with acromegaly and prolactinoma, aromatase was high, was negatively correlated with Ki-67 score, and was higher in the pituitary of patients with complete postoperative remission than without remission [12].

\section{Estrogenic Receptors, Prolactinomas, and AIB1}

The biological effects of estrogens are mediated by their two nuclear receptors-estrogenic receptor $\alpha(E R \alpha)$ and estrogenic receptor $\beta(E R \beta)$ - both of which are necessary for hormone action in target tissues [94]. They play an important mitogenic role, stimulating the proliferation of lactotroph cells $[29,95]$, acting directly on these cells. The presence of estrogen receptors in the pituitary gland has been described in adult rats of both sexes as well as the direct action of estradiol on pituitary cells $[51,56,96]$. The expression of ER $\alpha$ and ER $\beta$ are also present in human pituitary adenomas $[48,97,98]$. However, in male rats, the expression of ER $\alpha$ is very high compared with ER $\beta$ in the anterior pituitary [94].

In animals and human studies, estrogens induce the expression of pituitary tumor transforming gene (PTTG), a proto-oncogene that regulates cell cycle progression, proliferation, differentiation, repair, transformation, and angiogenesis [99]. This proto-oncogene is weakly expressed in normal tissues; however, it is widely detected in malignant cell lines and in most pituitary tumors, including prolactinomas $[100,101]$. Likewise, PTTG stimulates fibroblast growth factor 2 (FGF2) and vascular endothelial growth factor (VEGF) production, accelerates tissue angiogenesis, and facilitates pituitary tumor progression through local invasion of the surrounding tissues [99,102]. On the other hand, AIB1, an important factor in the development of breast cancer [103], is overexpressed by the action of 17- $\beta$-estradiol [104], and AIB1 may be an important diagnostic and therapeutic target in 
breast cancer [105]. The relation between ER $\alpha$ and AIB1 is well established $[103,106,107]$, and the over-expression of AIB1 could be related to the increases in the incidence of pituitary tumors in mice [108].

Previous findings from our laboratory demonstrate that the overexpression of aromatase in human prolactinomas was associated with the presence of the ER $\alpha$ and the overexpression of the estrogenic mitogen coactivator AIB1 [30] and could be related to proliferative or anti-apoptotic roles of AIB1 as has been described for others tumors [108-113]. One of the most interesting results observed in these study was the presence of a different, cytoplasmic or/and nuclear, subcellular distribution of AIB1: $17 \%$ showed reaction only in the cytoplasm, $24 \%$ presented it only in the nucleus, and $59 \%$ had both cytoplasmic and nuclear reactions. As a translational coactivator, AIB1 develops its action in the cell nucleus. In fact, in quiescent mammary epithelial cells or cell cultures devoid of growth factors, it is located in the cell cytoplasm [96]; however, when the nuclear localization predominates, cells are proliferated [98] in a manner similar to that in which the development of breast tumors occurs [114].

In cell lines, AIB1 can be observed in different subcellular compartments, cytoplasmic or nuclear [115,116], a fact has been linked with its degradation. Cytoplasmic AIB1 has a half-life longer than nuclear AIB1, suggesting the existence of cytoplasmic lysosomal degradation, although less important than nuclear degradation, which is carried out by the MG132 proteasome [115]. Intranuclear localization of AIB1 could be related to the activation of estrogen receptors, whereas cytoplasmic localization AIB1 could be linked to an increase in half-life and activation AP-1. In the case of the pituitary gland and in particular the prolactin cells, AP- 1 is one of the most important mechanisms in the activation of these cells [117]. Therefore, the nuclear localization of AIB1 in prolactinomas is associated with the cellular proliferative status, whereas cytoplasmic-AIB1 is related to apoptosis [30].

\section{P53 and P27 Proteins in Prolactinomas}

The p53 protein is a nuclear phosphoprotein that acts as a tumor suppressor by inhibiting cell cycle progression and the phosphorylation of retinoblastoma protein [118]. Its function is altered, generally, by point mutations in the gene encoding it in over 50\% of human cancers [119]. The relationship between estrogen receptor and p53 has already been corroborated [120-123]. It is suggested that ER $\alpha$ directly interacts with $\mathrm{p} 53$, and this association could prevent the p53-mediated apoptotic response [122]. ER $\alpha$ antagonizes the pro-apoptotic function of p53, promoting cancer cell survival. Recently, in breast cancer cells, it has been shown that ER $\beta$ physically interacts with p53, reduces ER $\alpha$-p53 binding, antagonizes ER $\alpha$-p53-mediated transcriptional regulation, and could generate changes epigenetic in histone methylation [121]. P53 also inhibits the expression of aromatase by binding to a 553 response element on the aromatase promoter to be repressed by prostaglandin E2 (PGE2). It was demonstrated that the loss of p53 leads to the stabilization of hypoxia-inducible factor 1-alpha (HIF1 $\alpha$ ) and metabolic regulator protein kinase M2 (PKM2) besides stimulates their interaction with the aromatase promoter and induces an increase in aromatase expression and activity [124].

The presence of p53 in pituitary adenomas is well documented in the literature [26,88,125-128]. The importance of the role that p53 can play in the cytophysiology and the progression of pituitary adenomas has become relevant since DNA damage in cells from pituitary tumor lines induces the cell cycle arrest mediated by p53 and determines whether or not reparable damage occurs before continuing with cell division $[129,130]$. Therefore, mutation, deletion, or p53 inactivation clearly favors tumor progression.

There may be some relationship between factors involved in the development of prolactinomas and the role played by $\mathrm{p} 53$ and Bcl-2. In the pituitary gland, the pituitary apoptosis associated with increased p53 appears only at very low levels or the absence of estrogen [131]. On the other hand, the apoptotic activity in the pituitary adenomas treated with bromocriptine depends on activation of p53 and suppression of Bcl-2 [132]. Despite the fact that p53 expression is reported to be associated with the tumor invasiveness in pituitary tumors, there are few reports on the role of p53-dependent apoptosis in pituitary tumor therapy [133]. Additionally, the presence of p53 in invasive or large human 
pituitary adenomas $[26,127]$ is controversial. However, it has been established that the expression of p53 is very important when assessing the prediction of the behavior that follows human pituitary adenomas [88,134], with a higher expression in recurrent adenomas compared to those that are non-recurring [135] and adenomas bromocriptine-resistant [100]. In our laboratory, we found that around $76 \%$ of prolactinomas were positive for $\mathrm{p} 53$, similar to results described previously by other laboratories [125]. However, there are few studies analyzing the percentage of p53-positive pituitary adenomas and, in general, the few studies that analyze this data refer mainly to pituitary adenomas in general or pituitary tumor lines instead of prolactinomas in particular [26].

There are no descriptions relating to the intracellular localization of p53 with other biological actions. Given that p53 is a protein that carries out its action in the nucleus, the arrest of p53 in the cytoplasm of tumor cells could avoid its biological action on DNA binding to promoters that regulate the cell cycle and apoptosis. We have seen that the pattern of reaction to p53 and in particular, the intracellular localization of the reaction varies greatly from one tumor to another. Although $76 \%$ of prolactinomas showed positive p53 cells, $58 \%$ of p53-positive prolactinomas showed some isolated p53-positive cells. It is very important to consider that in the prolactinomas that showed many positive p53 cells, the protein was arrested in the cytoplasm, and, although some cells could have a nuclear reaction these cells were very low, always below $0.6 \%$ of the positive cells.

In pituitary tumor cell lines, bromocriptine-resistant p53 adopts a mutant conformation that precludes its nuclear translocation and transcriptional activity [136]. However, mutations of p53 in pituitary benign adenomas have not been described [26,137]. In most of the p53-positive human prolactinomas, the protein is located in the cytoplasm of the cell and the intracellular localization of the protein could be very important in the growth of the tumor. In addition, AIB1 and p53 could be related to in the pathogenesis of prolactinomas because, in HeLa cells, p53 interacts with specific "rub" regions of AIB1, and AIB1 can modulate p53 transactivation [138]. This is similar to what occurs in other tumors, such as the correlation between the overexpression of AIB1 and p53 positivity in breast cancer [106] or in colorectal cancer [139].

$\mathrm{P} 27 /(\mathrm{KIP} 1)$ is a cyclin-dependent kinase inhibitor that plays important roles in the regulation of cell-cycle progression [134]. An increase in levels of p27/KIP1 protein typically causes cells to arrest in the G1 phase of the cell cycle [140]. In different types of tumors, it has been revealed that growth factors present outside epithelial cells, such as transforming growth factor beta (TFG $\beta$ ), arouse p27 levels inside a cell [133]. Several studies found significantly lower p27/KIP1 levels in non-functioning adenomas [141], although other research has exhibited higher proliferation rates in these tumors [142]. There is evidence that p27 protein expression decreases during development and progression in pituitary adenomas, including prolactinomas, compared with the normal gland $[90,133,143]$. Recurrent adenomas and malignant tumors showed a p27/KIP1 expression that was lower than non-recurrent adenomas. However, different studies have failed to detect any mutations within the p27 gen [144]. The significance and mechanisms underlying reduced p27/KIP1 levels in pituitary tumors is uncertain.

Recently, Martins and co-workers [145] have confirmed p27 underexpression in pituitary adenomas and have thus provided further evidence of the involvement of the post-translational machinery, although this phenomenon cannot be explained either by the mis-expression of p27 translational regulators DKC1, RPS13, miR221, and miR222 or by DKC1 mutations directly. For the moment, the participation of p27 in the development and evolution of prolactinomas is unclear and requires further research.

\section{Conclusions}

Because aromatase is synthesized in the pituitary gland, it has been able to produce estradiol locally in several types of endocrine cells. Our previous results suggest that aromatase is an auto-paracrine regulatory factor by means of estrogens for the maintenance of the population of lactotroph cells and that it modulates the action of central or peripheral regulators. Moreover, its overexpression is present in prolactinomas. Estrogens are involved in the regulation of the 
proliferation and apoptosis, which play an important role in the maintenance of pituitary cell populations, and implicated in the pathogeny of anterior pituitary tumors, especially prolactinomas. The clinical relevance for the role of aromatase in the genesis and/or growth of prolactinomas, and the consideration of aromatase as a therapeutic target, mainly in dopaminergic-resistant tumors, are fields that need be explored.

Author Contributions: All the authors of the manuscript participated equally.

Conflicts of Interest: The authors declare no conflict of interest.

\section{Abbreviations}

NADPH Nicotinamide adenine dinucleotide phosphate

LH Luteinizing hormone

PRL Prolactin

VIP Vasoactive intestinal polypeptide

TRH Thyrotropin-releasing hormone

IGF-IR Insulin-like growth factor 1 receptor

EGFR Epidermal growth factor receptor

MAPK Mitogen-activated protein kinase

BAX Bcl-2-like protein 4

NF- $\mathrm{KB} \quad$ Nuclear factor kappa-light-chain-enhancer of activated B cells

ER Estrogenic receptor

PTTG Pituitary tumor transforming gene

VEGF Vascular endothelial growth factor

AIB1 Amplified in breast 1 protein

PCNA Proliferating cell nuclear antigen

\section{References}

1. Blakemore, J.; Naftolin, F. Aromatase: Contributions to physiology and disease in women and men. Physiology 2016, 31, 258-269. [CrossRef] [PubMed]

2. Simpson, E.R.; Zhao, Y.; Agarwal, V.R.; Michael, M.D.; Bulun, S.E.; Hinshelwood, M.M.; Graham-Lorence, S.; Sun, T.; Fisher, C.R.; Qin, K.; et al. Aromatase expression in health and disease. Recent Prog. Horm. Res. 1997, 52, 185-213. [PubMed]

3. Carson-Jurica, M.A.; Schrader, W.T.; O'Malley, B.W. Steroid receptor family: Structure and functions. Endocr. Rev. 1990, 11, 201-220. [CrossRef] [PubMed]

4. Cheskis, B.J.; Greger, J.G.; Nagpal, S.; Freedman, L.P. Signaling by estrogens. J. Cell. Physiol. 2007, 213, 610-617. [CrossRef] [PubMed]

5. Sar, M.; Lubahn, D.B.; French, F.S.; Wilson, E.M. Immunohistochemical localization of the androgen receptor in rat and human tissues. Endocrinology 1990, 127, 3180-3186. [CrossRef] [PubMed]

6. Zubeldia-Brenner, L.; Roselli, C.E.; Recabarren, S.E.; Gonzalez Deniselle, M.C.; Lara, H.E. Developmental and functional effects of steroid hormones on the neuroendocrine axis and spinal cord. J. Neuroendocrinol. 2016, 28. [CrossRef] [PubMed]

7. Simpson, E.R.; Clyne, C.; Rubin, G.; Boon, W.C.; Robertson, K.; Britt, K.; Speed, C.; Jones, M. Aromatase-A brief overview. Annu. Rev. Physiol. 2002, 64, 93-127. [CrossRef] [PubMed]

8. Carretero, J.; Burks, D.J.; Vazquez, G.; Rubio, M.; Hernandez, E.; Bodego, P.; Vazquez, R. Expression of aromatase p450 is increased in spontaneous prolactinomas of aged rats. Pituitary 2002, 5, 5-10. [CrossRef] [PubMed]

9. Gonzales, P.H.; Mezzomo, L.C.; Ferreira, N.P.; Roehe, A.V.; Kohek, M.B.; Oliveira Mda, C. Aromatase p450 expression in human pituitary adenomas. Neuropathology 2015, 35, 16-23. [CrossRef] [PubMed]

10. Morale, M.C.; L’Episcopo, F.; Tirolo, C.; Giaquinta, G.; Caniglia, S.; Testa, N.; Arcieri, P.; Serra, P.A.; Lupo, G.; Alberghina, M.; et al. Loss of aromatase cytochrome p450 function as a risk factor for Parkinson's disease? Brain Res. Rev. 2008, 57, 431-443. [CrossRef] [PubMed] 
11. Patel, S. Disruption of aromatase homeostasis as the cause of a multiplicity of ailments: A comprehensive review. J. Steroid Biochem. Mol. Biol. 2017, 168, 19-25. [CrossRef] [PubMed]

12. Selek, A.; Cetinarslan, B.; Gurbuz, Y.; Tarkun, I.; Canturk, Z.; Cabuk, B. Aromatase enzyme expression in acromegaly and its possible relationship with disease prognosis. Endocrine 2015, 49, 250-257. [CrossRef] [PubMed]

13. Hickey, G.J.; Krasnow, J.S.; Beattie, W.G.; Richards, J.S. Aromatase cytochrome p450 in rat ovarian granulosa cells before and after luteinization: Adenosine $3^{\prime}, 5^{\prime}$-monophosphate-dependent and independent regulation. Cloning and sequencing of rat aromatase cdna and 5' genomic DNA. Mol. Endocrinol. 1990, 4, 3-12. [CrossRef] [PubMed]

14. Barney, M.L.; Patil, J.G.; Gunasekera, R.M.; Carter, C.G. Distinct cytochrome p450 aromatase isoforms in the common carp (Cyprinus carpio): Sexual dimorphism and onset of ontogenic expression. Gen. Comp. Endocrinol. 2008, 156, 499-508. [CrossRef] [PubMed]

15. Ezzat, S.; Asa, S.L.; Couldwell, W.T.; Barr, C.E.; Dodge, W.E.; Vance, M.L.; McCutcheon, I.E. The prevalence of pituitary adenomas: A systematic review. Cancer 2004, 101, 613-619. [CrossRef] [PubMed]

16. Daly, A.F.; Rixhon, M.; Adam, C.; Dempegioti, A.; Tichomirowa, M.A.; Beckers, A. High prevalence of pituitary adenomas: A cross-sectional study in the province of liege, belgium. J. Clin. Endocrinol. Metab. 2006, 91, 4769-4775. [CrossRef] [PubMed]

17. Fernandez, A.; Karavitaki, N.; Wass, J.A. Prevalence of pituitary adenomas: A community-based, cross-sectional study in Banbury (Oxfordshire, UK). Clin. Endocrinol. 2010, 72, 377-382. [CrossRef] [PubMed]

18. Asa, S.L.; Ezzat, S. The cytogenesis and pathogenesis of pituitary adenomas. Endocr. Rev. 1998, 19, 798-827. [CrossRef] [PubMed]

19. Levy, A.; Lightman, S. Molecular defects in the pathogenesis of pituitary tumours. Front. Neuroendocrinol. 2003, 24, 94-127. [CrossRef]

20. Li, N.; Jiang, Z. Relationship between expression of vascular endothelial growth factor and the proliferation of prolactinomas. Clin. Neurol. Neurosurg. 2017, 153, 102-106. [CrossRef] [PubMed]

21. Ragel, B.T.; Couldwell, W.T. Pituitary carcinoma: A review of the literature. Neurosurg. Focus 2004, 16, E7. [CrossRef] [PubMed]

22. Gillam, M.P.; Molitch, M.E.; Lombardi, G.; Colao, A. Advances in the treatment of prolactinomas. Endocr. Rev. 2006, 27, 485-534. [CrossRef] [PubMed]

23. Seltzer, J.; Scotton, T.C.; Kang, K.; Zada, G.; Carmichael, J.D. Gene expression in prolactinomas: A systematic review. Pituitary 2016, 19, 93-104. [CrossRef] [PubMed]

24. Mindermann, T.; Wilson, C.B. Age-related and gender-related occurrence of pituitary adenomas. Clin. Endocrinol. 1994, 41, 359-364. [CrossRef]

25. Sarkar, D.K. Genesis of prolactinomas: Studies using estrogen-treated animals. Front. Horm. Res. 2006, 35, 32-49. [PubMed]

26. Saeger, W.; Ludecke, B.; Ludecke, D.K. Clinical tumor growth and comparison with proliferation markers in non-functioning (inactive) pituitary adenomas. Exp. Clin. Endocrinol. Diabetes 2008, 116, 80-85. [CrossRef] [PubMed]

27. Heaney, A.P.; Fernando, M.; Melmed, S. Functional role of estrogen in pituitary tumor pathogenesis. J. Clin. Investig. 2002, 109, 277-283. [CrossRef] [PubMed]

28. Faglia, G.; Spada, A. Genesis of pituitary adenomas: State of the art. J. Neuro Oncol. 2001, 54, 95-110. [CrossRef]

29. Lloyd, R.V.; Jin, L.; Fields, K.; Kulig, E. Effects of estrogens on pituitary cell and pituitary tumor growth. Pathol. Res. Pract. 1991, 187, 584-586. [CrossRef]

30. Carretero, J.; Blanco, E.J.; Carretero, M.; Carretero-Hernandez, M.; Garcia-Barrado, M.J.; Iglesias-Osma, M.C.; Burks, D.J.; Font de Mora, J. The expression of aib1 correlates with cellular proliferation in human prolactinomas. Ann. Anat. 2013, 195, 253-259. [CrossRef] [PubMed]

31. Carretero, J.; Vazquez, G.; Blanco, E.; Rubio, M.; Santos, M.; Martin-Clavijo, A.; Torres, J.L.; Vazquez, R. Immunohistochemical evidence of the presence of aromatase p450 in the rat hypophysis. Cell Tissue Res. 1999, 295, 419-423. [CrossRef] [PubMed]

32. Bender, R.A.; Zhou, L.; Vierk, R.; Brandt, N.; Keller, A.; Gee, C.E.; Schafer, M.K.; Rune, G.M. Sex-dependent regulation of aromatase-mediated synaptic plasticity in the basolateral amygdala. J. Neurosci. 2017, 37, 1532-1545. [CrossRef] [PubMed] 
33. Biegon, A. In vivo visualization of aromatase in animals and humans. Front. Neuroendocrinol. 2016, 40, 42-51. [CrossRef] [PubMed]

34. Cisternas, C.D.; Cabrera Zapata, L.E.; Arevalo, M.A.; Garcia-Segura, L.M.; Cambiasso, M.J. Regulation of aromatase expression in the anterior amygdala of the developing mouse brain depends on ER $\beta$ and sex chromosome complement. Sci. Rep. 2017, 7, 5320. [CrossRef] [PubMed]

35. Galmiche, G.; Corvaisier, S.; Kottler, M.L. Aromatase gene expression and regulation in the female rat pituitary. Ann. N. Y. Acad. Sci. 2006, 1070, 286-292. [CrossRef] [PubMed]

36. Kadioglu, P.; Oral, G.; Sayitoglu, M.; Erensoy, N.; Senel, B.; Gazioglu, N.; Sav, A.; Cetin, G.; Ozbek, U. Aromatase cytochrome p450 enzyme expression in human pituitary. Pituitary 2008, 11, 29-35. [CrossRef] [PubMed]

37. Nocillado, J.N.; Elizur, A.; Avitan, A.; Carrick, F.; Levavi-Sivan, B. Cytochrome p450 aromatase in grey mullet: Cdna and promoter isolation; brain, pituitary and ovarian expression during puberty. Mol. Cell. Endocrinol. 2007, 263, 65-78. [CrossRef] [PubMed]

38. Boyar, R.M.; Perlow, M.; Kapen, S.; Lefkowitz, G.; Weitzman, E.; Hellman, L. The effect of clomiphene citrate on the 24-hour lh secretory pattern in normal men. J. Clin. Endocrinol. Metab. 1973, 36, 561-567. [CrossRef] [PubMed]

39. Carretero, J.; Vazquez, G.; Rubio, M.; Blanco, E.; Juanes, J.A.; Perez, E.; Burks, D.; Vazquez, R. Postnatal differentiation of the immunohistochemical expression of aromatase p450 in the rat pituitary gland. Histol. Histopathol. 2003, 18, 419-423. [PubMed]

40. Carretero, J.; Lopez, F.; Catalano-Iniesta, L.; Sanchez-Robledo, V.; Garcia-Barrado, M.J.; Iglesias-Osma, M.C.; Carretero-Hernandez, M.; Blanco, E.J.; Burks, D.J. Pituitary aromatase p450 may be involved in maintenance of the population of luteinizing hormone-positive pituitary cells in mice. Cells Tissues Organs 2016, 201, 390-398. [CrossRef] [PubMed]

41. Garcia Barrado, M.J.; Blanco, E.J.; Carretero Hernandez, M.; Iglesias Osma, M.C.; Carretero, M.; Herrero, J.J.; Burks, D.J.; Carretero, J. Local transformations of androgens into estradiol by aromatase p450 is involved in the regulation of prolactin and the proliferation of pituitary prolactin-positive cells. PLoS ONE 2014, 9, e101403. [CrossRef] [PubMed]

42. Carretero, J.; Blanco, E.J.; Iglesias-Osma, M.C.; Carretero-Hernandez, M.; Carretero, M.; Vazquez, T.; Alvarez, P.; Garcia-Barrado, M.J. Morphological evidence of the relevance of aromatase 4450 in autoparacrine regulation and pathology of the hypophysis. Eur. J. Anat. 2015, 19, 229-247.

43. Barraclough, C.A.; Camp, P.; Weiland, N.; Akabori, A. Stimulatory versus inhibitory effects of progesterone on estrogen-induced phasic lh and prolactin secretion correlated with estrogen nuclear and progestin cytosol receptor concentrations in brain and pituitary gland. Neuroendocrinology 1986, 42, 6-14. [CrossRef] [PubMed]

44. Giguere, V.; Meunier, H.; Veilleux, R.; Labrie, F. Direct effects of sex steroids on prolactin release at the anterior pituitary level: Interactions with dopamine, thyrotropin-releasing hormone, and isobutylmethylxanthine. Endocrinology 1982, 111, 857-862. [CrossRef] [PubMed]

45. Kubota, T.; Kuan, S.I.; MacLeod, R.M. Effect of $17 \beta$-estradiol on phosphoinositide metabolism and prolactin secretion in anterior pituitary cells. Neuroendocrinology 1989, 50, 400-405. [CrossRef] [PubMed]

46. Maurer, R.A. Estradiol regulates the transcription of the prolactin gene. J. Biol. Chem. 1982, 257, $2133-2136$. [PubMed]

47. Ben-Jonathan, N.; Hnasko, R. Dopamine as a prolactin (PRL) inhibitor. Endocr. Rev. 2001, 22, 724-763. [CrossRef] [PubMed]

48. Friend, K.E.; Chiou, Y.K.; Lopes, M.B.; Laws, E.R., Jr.; Hughes, K.M.; Shupnik, M.A. Estrogen receptor expression in human pituitary: Correlation with immunohistochemistry in normal tissue, and immunohistochemistry and morphology in macroadenomas. J. Clin. Endocrinol. Metab. 1994, 78, 1497-1504. [PubMed]

49. Freeman, M.E.; Kanyicska, B.; Lerant, A.; Nagy, G. Prolactin: Structure, function, and regulation of secretion. Physiol. Rev. 2000, 80, 1523-1631. [PubMed]

50. Carrillo, A.J.; Sharp, Z.D.; DePaolo, L.V. Correlation of rat pituitary prolactin messenger ribonucleic acid and hormone content with serum levels during the estrogen-induced surge. Endocrinology 1987, 121, 1993-1999. [CrossRef] [PubMed]

51. Shull, J.D.; Gorski, J. Estrogen regulates the transcription of the rat prolactin gene in vivo through at least two independent mechanisms. Endocrinology 1985, 116, 2456-2462. [CrossRef] [PubMed] 
52. Kansra, S.; Yamagata, S.; Sneade, L.; Foster, L.; Ben-Jonathan, N. Differential effects of estrogen receptor antagonists on pituitary lactotroph proliferation and prolactin release. Mol. Cell. Endocrinol. 2005, 239, 27-36. [CrossRef] [PubMed]

53. Carretero, J.; Angoso, M.; Rubio, M.; Blanco, E.J.; Sierra, E.; Herrero, J.J.; Perez, E.; Burks, D.J. In vitro immunoblockade of vip inhibits the proliferation of pituitary prolactin cells. Anat. Embryol. 2006, 211, 11-18. [CrossRef] [PubMed]

54. Goluboff, L.G.; Ezrin, C. Effect of pregnancy on the somatotroph and the prolactin cell of the human adenohypophysis. J. Clin. Endocrinol. Metab. 1969, 29, 1533-1538. [CrossRef] [PubMed]

55. Scheithauer, B.W.; Sano, T.; Kovacs, K.T.; Young, W.F., Jr.; Ryan, N.; Randall, R.V. The pituitary gland in pregnancy: A clinicopathologic and immunohistochemical study of 69 cases. Mayo Clin. Proc. 1990, 65, 461-474. [CrossRef]

56. Carretero, J.; Sanchez, F.; Blanco, E.; Montero, M.; Riesco, J.M.; Gonzalez, R.; Vazquez, R. Estrogenic modulation of met-enkephalin-induced prolactin secretion in rats. Anat. Embryol. 1991, 183, 455-459. [CrossRef] [PubMed]

57. Carretero, J.; Sanchez, F.; Blanco, E.; Riesco, J.M.; Sanchez-Franco, F.; Vazquez, R. Morphofunctional study of mammotropic cells following intraventricular administration of met-enkephalin. Anat. Embryol. 1989, 179, 243-250. [CrossRef] [PubMed]

58. Kineman, R.D.; Faught, W.J.; Frawley, L.S. Steroids can modulate transdifferentiation of prolactin and growth hormone cells in bovine pituitary cultures. Endocrinology 1992, 130, 3289-3294. [CrossRef] [PubMed]

59. Iglesias-Osma, M.C.; Blanco, E.J.; Carretero-Hernandez, M.; Garcia-Barrado, M.J.; Catalano-Iniesta, L.; Carretero, M.; Sanchez-Robledo, V.; Carretero, J. Endothelial immunocytochemical expression of pituitary IL-1 $\beta$ and its relation to ACTH-positive cells is regulated by corticosterone in the male rat. Cytokine 2017, 99, 9-17. [CrossRef] [PubMed]

60. Gibbs, D.M.; Neill, J.D. Dopamine levels in hypophysial stalk blood in the rat are sufficient to inhibit prolactin secretion in vivo. Endocrinology 1978, 102, 1895-1900. [CrossRef] [PubMed]

61. Saiardi, A.; Bozzi, Y.; Baik, J.H.; Borrelli, E. Antiproliferative role of dopamine: Loss of d2 receptors causes hormonal dysfunction and pituitary hyperplasia. Neuron 1997, 19, 115-126. [CrossRef]

62. Bowers, C.Y.; Friesen, H.G.; Hwang, P.; Guyda, H.J.; Folkers, K. Prolactin and thyrotropin release in man by synthetic pyroglutamyl-histidyl-prolinamide. Biochem. Biophys. Res. Commun. 1971, 45, 1033-1041. [CrossRef]

63. Jacobi, J.; Lloyd, H.M.; Meares, J.D. Onset of oestrogen-induced prolactin secretion and DNA synthesis by the rat pituitary gland. J. Endocrinol. 1977, 72, 35-39. [CrossRef] [PubMed]

64. Mitchner, N.A.; Garlick, C.; Steinmetz, R.W.; Ben-Jonathan, N. Differential regulation and action of estrogen receptors $\alpha$ and $\beta$ in gh3 cells. Endocrinology 1999, 140, 2651-2658. [CrossRef] [PubMed]

65. Watson, C.S.; Norfleet, A.M.; Pappas, T.C.; Gametchu, B. Rapid actions of estrogens in gh3/b6 pituitary tumor cells via a plasma membrane version of estrogen receptor- $\alpha$. Steroids 1999, 64, 5-13. [CrossRef]

66. Skandalis, S.S.; Afratis, N.; Smirlaki, G.; Nikitovic, D.; Theocharis, A.D.; Tzanakakis, G.N.; Karamanos, N.K. Cross-talk between estradiol receptor and EGFR/IGF-IR signaling pathways in estrogen-responsive breast cancers: Focus on the role and impact of proteoglycans. Matrix Biol. 2014, 35, 182-193. [CrossRef] [PubMed]

67. Ben-Shlomo, A.; Cooper, O. Role of tyrosine kinase inhibitors in the treatment of pituitary tumours: From bench to bedside. Curr. Opin. Endocrinol. Diabetes Obes. 2017, 24, 301-305. [CrossRef] [PubMed]

68. Liu, X.; Kano, M.; Araki, T.; Cooper, O.; Fukuoka, H.; Tone, Y.; Tone, M.; Melmed, S. Erbb receptor-driven prolactinomas respond to targeted lapatinib treatment in female transgenic mice. Endocrinology 2015, 156, 71-79. [CrossRef] [PubMed]

69. Flageng, M.H.; Larionov, A.; Geisler, J.; Knappskog, S.; Prestvik, W.S.; Bjorkoy, G.; Lilleng, P.K.; Dixon, J.M.; Miller, W.R.; Lonning, P.E.; et al. Treatment with aromatase inhibitors stimulates the expression of epidermal growth factor receptor-1 and neuregulin 1 in ER positive/HER-2/neu non-amplified primary breast cancers. J. Steroid Biochem. Mol. Biol. 2017, 165, 228-235. [CrossRef] [PubMed]

70. Baek, M.H.; Park, J.Y.; Rhim, C.C.; Kim, J.H.; Park, Y.; Kim, K.R.; Nam, J.H. Investigation of new therapeutic targets in undifferentiated endometrial sarcoma. Gynecol. Obstet. Investig. 2017, 82, 329-339. [CrossRef] [PubMed] 
71. Suzuki, A.; Okuda, K.; Yano, M.; Oda, R.; Sakane, T.; Kawano, O.; Haneda, H.; Moriyama, S.; Nakanishi, M.; Nakanishi, R. Exon 7 splicing variant of estrogen receptor $\alpha$ is associated with pathological invasiveness in smoking-independent lung adenocarcinoma. Oncol. Lett. 2017, 14, 891-898. [CrossRef] [PubMed]

72. Cocciadiferro, L.; Miceli, V.; Granata, O.M.; Carruba, G. Merlin, the product of nf2 gene, is associated with aromatase expression and estrogen formation in human liver tissues and liver cancer cells. J. Steroid Biochem. Mol. Biol. 2017, 172, 222-230. [CrossRef] [PubMed]

73. Garcia-Barrado, M.J.; Blanco, E.J.; Catalano-Iniesta, L.; Sanchez-Robledo, V.; Iglesias-Osma, M.C.; Carretero-Hernandez, M.; Rodriguez-Cobos, J.; Burks, D.J.; Carretero, J. Relevance of pituitary aromatase and estradiol on the maintenance of the population of prolactin-positive cells in male mice. Steroids 2016, 111, 121-126. [CrossRef] [PubMed]

74. Gillies, G.E.; McArthur, S. Independent influences of sex steroids of systemic and central origin in a rat model of Parkinson's disease: A contribution to sex-specific neuroprotection by estrogens. Horm. Behav. 2010, 57, 23-34. [CrossRef] [PubMed]

75. Clifton, K.H.; Meyer, R.K. Mechanism of anterior pituitary tumor induction by estrogen. Anat. Rec. 1956, 125, 65-81. [CrossRef] [PubMed]

76. Hsu, D.W.; Riskind, P.N.; Hedley-Whyte, E.T. Vasoactive intestinal peptide in the human pituitary gland and adenomas. An immunocytochemical study. Am. J. Pathol. 1989, 135, 329-338. [PubMed]

77. Phelps, C.J.; Hymer, W.C. Effects of bromocriptine on prolactin cellular hypertrophy, proliferation and secretory activity in diethylstilbestrol-induced pituitary tumors. Mol. Cell. Endocrinol. 1988, 58, 137-148. [CrossRef]

78. De Castro, F.; Moron, F.J.; Montoro, L.; Galan, J.J.; Real, L.M.; Ruiz, A. Re: Polymorphisms associated with circulating sex hormone levels in postmenopausal women. J. Natl. Cancer Inst. 2005, 97, 152-153. [CrossRef] [PubMed]

79. Artigalas, O.; Vanni, T.; Hutz, M.H.; Ashton-Prolla, P.; Schwartz, I.V. Influence of cyp19a1 polymorphisms on the treatment of breast cancer with aromatase inhibitors: A systematic review and meta-analysis. BMC Med. 2015, 13, 139. [CrossRef] [PubMed]

80. Akinci, H.; Kapucu, A.; Dar, K.A.; Celik, O.; Tutunculer, B.; Sirin, G.; Oz, B.; Gazioglu, N.; Ince, H.; Aliustaoglu, S.; et al. Aromatase cytochrome p450 enzyme expression in prolactinomas and its relationship to tumor behavior. Pituitary 2013, 16, 386-392. [CrossRef] [PubMed]

81. Heidari, Z.; Hosseinpanah, F.; Shirazian, N. Achievement of fertility in an infertile man with resistant macroprolactinoma using high-dose bromocriptine and a combination of human chorionic gonadotropin and an aromatase inhibitor. Endocr. Pract. 2010, 16, 669-672. [CrossRef] [PubMed]

82. Molitch, M.E. Management of medically refractory prolactinoma. J. Neuro Oncol. 2014, 117, 421-428. [CrossRef] [PubMed]

83. Molitch, M.E. Pharmacologic resistance in prolactinoma patients. Pituitary 2005, 8, 43-52. [CrossRef] [PubMed]

84. Gillam, M.P.; Middler, S.; Freed, D.J.; Molitch, M.E. The novel use of very high doses of cabergoline and a combination of testosterone and an aromatase inhibitor in the treatment of a giant prolactinoma. J. Clin. Endocrinol. Metab. 2002, 87, 4447-4451. [CrossRef] [PubMed]

85. Carbajo-Perez, E.; Watanabe, Y.G. Cellular proliferation in the anterior pituitary of the rat during the postnatal period. Cell Tissue Res. 1990, 261, 333-338. [CrossRef] [PubMed]

86. Takahashi, S.; Okazaki, K.; Kawashima, S. Mitotic activity of prolactin cells in the pituitary glands of male and female rats of different ages. Cell Tissue Res. 1984, 235, 497-502. [CrossRef] [PubMed]

87. Drewett, N.; Jacobi, J.M.; Willgoss, D.A.; Lloyd, H.M. Apoptosis in the anterior pituitary gland of the rat: Studies with estrogen and bromocriptine. Neuroendocrinology 1993, 57, 89-95. [CrossRef] [PubMed]

88. Kontogeorgos, G. Predictive markers of pituitary adenoma behavior. Neuroendocrinology 2006, 83, $179-188$. [CrossRef] [PubMed]

89. Ibrahim, A.E.; Pickering, R.M.; Gawne-Cain, M.L.; King, S.; Lees, P.D.; Ellison, D.W. Indices of apoptosis and proliferation as potential prognostic markers in non-functioning pituitary adenomas. Clin. Neuropathol. 2004, 23, 8-15. [PubMed]

90. Nakabayashi, H.; Sunada, I.; Hara, M. Immunohistochemical analyses of cell cycle-related proteins, apoptosis, and proliferation in pituitary adenomas. J. Histochem. Cytochem. 2001, 49, 1193-1194. [CrossRef] [PubMed] 
91. Seilicovich, A. Cell life and death in the anterior pituitary gland: Role of oestrogens. J. Neuroendocrinol. 2010, 22, 758-764. [CrossRef] [PubMed]

92. Zaldivar, V.; Magri, M.L.; Zarate, S.; Jaita, G.; Eijo, G.; Radl, D.; Ferraris, J.; Pisera, D.; Seilicovich, A. Estradiol increases the bax/bcl-2 ratio and induces apoptosis in the anterior pituitary gland. Neuroendocrinology 2009, 90, 292-300. [CrossRef] [PubMed]

93. Magri, M.L.; Gottardo, M.F.; Zarate, S.; Eijo, G.; Ferraris, J.; Jaita, G.; Ayala, M.M.; Candolfi, M.; Pisera, D.; Seilicovich, A. Opposite effects of dihydrotestosterone and estradiol on apoptosis in the anterior pituitary gland from male rats. Endocrine 2016, 51, 506-516. [CrossRef] [PubMed]

94. Kuiper, G.G.; Enmark, E.; Pelto-Huikko, M.; Nilsson, S.; Gustafsson, J.A. Cloning of a novel receptor expressed in rat prostate and ovary. Proc. Natl. Acad. Sci. USA 1996, 93, 5925-5930. [CrossRef] [PubMed]

95. Amara, J.F.; van Itallie, C.; Dannies, P.S. Regulation of prolactin production and cell growth by estradiol: Difference in sensitivity to estradiol occurs at level of messenger ribonucleic acid accumulation. Endocrinology 1987, 120, 264-271. [CrossRef] [PubMed]

96. Carretero, J.; Rubio, M.; Navarro, N.; Prieto, P.; Vazquez, R.J.; Sanchez, F.; Vazquez, R. In vitro modifications in the proliferation rate of prolactin cells are accompanied by nuclear morphometric variations. Histol. Histopathol. 1995, 10, 135-139. [PubMed]

97. Manoranjan, B.; Salehi, F.; Scheithauer, B.W.; Rotondo, F.; Kovacs, K.; Cusimano, M.D. Estrogen receptors $\alpha$ and $\beta$ immunohistochemical expression: Clinicopathological correlations in pituitary adenomas. Anticancer Res. 2010, 30, 2897-2904. [PubMed]

98. Shupnik, M.A.; Pitt, L.K.; Soh, A.Y.; Anderson, A.; Lopes, M.B.; Laws, E.R., Jr. Selective expression of estrogen receptor $\alpha$ and $\beta$ isoforms in human pituitary tumors. J. Clin. Endocrinol. Metab. 1998, 83, 3965-3972. [CrossRef] [PubMed]

99. Ozkaya, H.M.; Comunoglu, N.; Keskin, F.E.; Oz, B.; Haliloglu, O.A.; Tanriover, N.; Gazioglu, N.; Kadioglu, P. Locally produced estrogen through aromatization might enhance tissue expression of pituitary tumor transforming gene and fibroblast growth factor 2 in growth hormone-secreting adenomas. Endocrine 2016, 52, 632-640. [CrossRef] [PubMed]

100. Spada, A.; Mantovani, G.; Lania, A. Pathogenesis of prolactinomas. Pituitary 2005, 8, 7-15. [CrossRef] [PubMed]

101. Zhang, X.; Horwitz, G.A.; Heaney, A.P.; Nakashima, M.; Prezant, T.R.; Bronstein, M.D.; Melmed, S. Pituitary tumor transforming gene (PTTG) expression in pituitary adenomas. J. Clin. Endocrinol. Metab. 1999, 84, 761-767. [CrossRef] [PubMed]

102. Pawlikowski, M. Endocrine/paracrine control of pituitary cell proliferation and its involvement in pituitary tumorigenesis. Pituitary 1999, 1, 251-256. [CrossRef] [PubMed]

103. Chang, A.K.; Wu, H. The role of aib1 in breast cancer. Oncol. Lett. 2012, 4, 588-594. [PubMed]

104. Edwards, D.P. Regulation of signal transduction pathways by estrogen and progesterone. Annu. Rev. Physiol. 2005, 67, 335-376. [CrossRef] [PubMed]

105. Osborne, C.K.; Bardou, V.; Hopp, T.A.; Chamness, G.C.; Hilsenbeck, S.G.; Fuqua, S.A.; Wong, J.; Allred, D.C.; Clark, G.M.; Schiff, R. Role of the estrogen receptor coactivator AIB1 (SRC-3) and HER-2/neu in tamoxifen resistance in breast cancer. J. Natl. Cancer Inst. 2003, 95, 353-361. [CrossRef] [PubMed]

106. Bouras, T.; Southey, M.C.; Venter, D.J. Overexpression of the steroid receptor coactivator aib1 in breast cancer correlates with the absence of estrogen and progesterone receptors and positivity for p53 and her $2 /$ neu. Cancer Res. 2001, 61, 903-907. [PubMed]

107. Wang, M.; Zhao, F.; Li, S.; Chang, A.K.; Jia, Z.; Chen, Y.; Xu, F.; Pan, H.; Wu, H. AIB1 cooperates with ER $\alpha$ to promote epithelial mesenchymal transition in breast cancer through SNAI1 activation. PLoS ONE 2013, 8, e65556. [CrossRef] [PubMed]

108. Torres-Arzayus, M.I.; Font de Mora, J.; Yuan, J.; Vazquez, F.; Bronson, R.; Rue, M.; Sellers, W.R.; Brown, M. High tumor incidence and activation of the pi3k/akt pathway in transgenic mice define aib1 as an oncogene. Cancer Cell. 2004, 6, 263-274. [CrossRef] [PubMed]

109. Avivar, A.; Garcia-Macias, M.C.; Ascaso, E.; Herrera, G.; O'Connor, J.E.; Font de Mora, J. Moderate overexpression of aib1 triggers pre-neoplastic changes in mammary epithelium. FEBS Lett. 2006, 580, 5222-5226. [CrossRef] [PubMed]

110. Horiguchi, K.; Arai, S.; Nishihara, T.; Nishikawa, J. Aib1 promotes DNA replication by jnk repression and akt activation during cellular stress. J. Biochem. 2006, 140, 409-419. [CrossRef] [PubMed] 
111. Marcantonio, D.; Chalifour, L.E.; Alaoui, J.; Ma, H.T.H.; Alaoui-Jamali, M.A.; Alaoui-Jamali, M.A.; Huynh, H.T.; Huynh, H.T. Steroid-sensitive gene-1 is an androgen-regulated gene expressed in prostatic smooth muscle cells in vivo. J. Mol. Endocrinol. 2001, 26, 175-184. [CrossRef] [PubMed]

112. Planas-Silva, M.D.; Shang, Y.; Donaher, J.L.; Brown, M.; Weinberg, R.A. Aib1 enhances estrogen-dependent induction of cyclin d1 expression. Cancer Res. 2001, 61, 3858-3862. [PubMed]

113. Zhou, H.J.; Yan, J.; Luo, W.; Ayala, G.; Lin, S.H.; Erdem, H.; Ittmann, M.; Tsai, S.Y.; Tsai, M.J. SRC-3 is required for prostate cancer cell proliferation and survival. Cancer Res. 2005, 65, 7976-7983. [CrossRef] [PubMed]

114. Kuang, S.Q.; Liao, L.; Zhang, H.; Lee, A.V.; O'Malley, B.W.; Xu, J. AIB1/SRC-3 deficiency affects insulin-like growth factor I signaling pathway and suppresses $\mathrm{v}$-Ha-ras-induced breast cancer initiation and progression in mice. Cancer Res. 2004, 64, 1875-1885. [CrossRef] [PubMed]

115. Ferrero, M.; Avivar, A.; Garcia-Macias, M.C.; Font de Mora, J. Phosphoinositide 3-kinase/AKT signaling can promote AIB1 stability independently of gsk3 phosphorylation. Cancer Res. 2008, 68, 5450-5459. [CrossRef] [PubMed]

116. Mani, A.; Oh, A.S.; Bowden, E.T.; Lahusen, T.; Lorick, K.L.; Weissman, A.M.; Schlegel, R.; Wellstein, A.; Riegel, A.T. E6ap mediates regulated proteasomal degradation of the nuclear receptor coactivator amplified in breast cancer 1 in immortalized cells. Cancer Res. 2006, 66, 8680-8686. [CrossRef] [PubMed]

117. Caccavelli, L.; Morange-Ramos, I.; Kordon, C.; Jaquet, P.; Enjalbert, A. Alteration of $g$ a subunits mrna levels in bromocriptine resistant prolactinomas. J. Neuroendocrinol. 1996, 8, 737-746. [CrossRef] [PubMed]

118. Vogelstein, B.; Kinzler, K.W. P53 function and dysfunction. Cell 1992, 70, 523-526. [CrossRef]

119. Chang, F.; Syrjanen, S.; Kurvinen, K.; Syrjanen, K. The p53 tumor suppressor gene as a common cellular target in human carcinogenesis. Am. J. Gastroenterol. 1993, 88, 174-186. [PubMed]

120. Bailey, S.T.; Shin, H.; Westerling, T.; Liu, X.S.; Brown, M. Estrogen receptor prevents p53-dependent apoptosis in breast cancer. Proc. Natl. Acad. Sci. USA 2012, 109, 18060-18065. [CrossRef] [PubMed]

121. Lu, W.; Katzenellenbogen, B.S. Estrogen receptor- $\beta$ modulation of the er $\alpha$-p53 loop regulating gene expression, proliferation, and apoptosis in breast cancer. Horm. Cancer 2017, 8, 230-242. [CrossRef] [PubMed]

122. Sayeed, A.; Konduri, S.D.; Liu, W.; Bansal, S.; Li, F.; Das, G.M. Estrogen receptor $\alpha$ inhibits p53-mediated transcriptional repression: Implications for the regulation of apoptosis. Cancer Res. 2007, 67, 7746-7755. [CrossRef] [PubMed]

123. Wang, X.; Simpson, E.R.; Brown, K.A. P53: Protection against tumor growth beyond effects on cell cycle and apoptosis. Cancer Res. 2015, 75, 5001-5007. [CrossRef] [PubMed]

124. Zahid, H.; Simpson, E.R.; Brown, K.A. Inflammation, dysregulated metabolism and aromatase in obesity and breast cancer. Curr. Opin. Pharmacol. 2016, 31, 90-96. [CrossRef] [PubMed]

125. Botelho, C.H.; Magalhaes, A.V.; Mello, P.A.; Schmitt, F.C.; Casulari, L.A. Expression of p53, Ki-67 and c-erb B2 in growth hormone-and/or prolactin-secreting pituitary adenomas. Arq Neuropsiquiatr. 2006, 64, 60-66. [CrossRef] [PubMed]

126. Huang, J.; Zhang, F.; Jiang, L.; Hu, G.; Sun, W.; Zhang, C.; Ding, X. Inhibition of skp2 sensitizes bromocriptine-induced apoptosis in human prolactinoma cells. Cancer Res. Treat. 2017, 49, 358-373. [CrossRef] [PubMed]

127. Oliveira, M.C.; Marroni, C.P.; Pizarro, C.B.; Pereira-Lima, J.F.; Barbosa-Coutinho, L.M.; Ferreira, N.P. Expression of p53 protein in pituitary adenomas. Braz. J. Med. Biol. Res. 2002, 35, 561-565. [CrossRef] [PubMed]

128. Phillips, J.; East, H.E.; French, S.E.; Melcescu, E.; Hamilton, R.D.; Nicholas, W.C.; Fratkin, J.F.; Parent, A.D.; Luzardo, G.; Koch, C.A. What causes a prolactinoma to be aggressive or to become a pituitary carcinoma? Hormones 2012, 11, 477-482. [CrossRef] [PubMed]

129. Clarke, A.R. Murine models of neoplasia: Functional analysis of the tumour suppressor genes rb-1 and p53. Cancer Metastasis Rev. 1995, 14, 125-148. [CrossRef] [PubMed]

130. Woloschak, M.; Yu, A.; Xiao, J. Molecular and cellular responses to DNA damage in a murine pituitary adenoma cell line. Mol. Cell. Endocrinol. 1996, 119, 61-68. [CrossRef]

131. Aoki, M.P.; Aoki, A.; Maldonado, C.A. Sexual dimorphism of apoptosis in lactotrophs induced by bromocryptine. Histochem. Cell. Biol. 2001, 116, 215-222. [CrossRef] [PubMed]

132. Yin, D.; Tamaki, N.; Kokunai, T.; Yasuo, K.; Yonezawa, K. Bromocriptine-induced apoptosis in pituitary adenoma cells: Relationship to p53 and bcl-2 expression. J. Clin. Neurosci. 1999, 6, 326-331. [CrossRef] 
133. Sav, A.; Rotondo, F.; Syro, L.V.; Scheithauer, B.W.; Kovacs, K. Biomarkers of pituitary neoplasms. Anticancer Res. 2012, 32, 4639-4654. [PubMed]

134. Polyak, K.; Kato, J.Y.; Solomon, M.J.; Sherr, C.J.; Massague, J.; Roberts, J.M.; Koff, A. P27kip1, a cyclin-cdk inhibitor, links transforming growth factor- $\beta$ and contact inhibition to cell cycle arrest. Genes Dev. 1994, 8, 9-22. [CrossRef] [PubMed]

135. Ozer, E.; Canda, M.S.; Ulukus, C.; Guray, M.; Erbayraktar, S. Expression of bcl-2, bax and p53 proteins in pituitary adenomas: An immunohistochemical study. Tumori 2003, 89, 54-59. [PubMed]

136. Facchetti, M.; Uberti, D.; Memo, M.; Missale, C. Nerve growth factor restores p53 function in pituitary tumor cell lines via trka-mediated activation of phosphatidylinositol 3-kinase. Mol. Endocrinol. 2004, 18, 162-172. [CrossRef] [PubMed]

137. Pernicone, P.J.; Scheithauer, B.W.; Sebo, T.J.; Kovacs, K.T.; Horvath, E.; Young, W.F., Jr.; Lloyd, R.V.; Davis, D.H.; Guthrie, B.L.; Schoene, W.C. Pituitary carcinoma: A clinicopathologic study of 15 cases. Cancer 1997, 79, 804-812. [CrossRef]

138. Lee, S.K.; Kim, H.J.; Kim, J.W.; Lee, J.W. Steroid receptor coactivator-1 and its family members differentially regulate transactivation by the tumor suppressor protein p53. Mol. Endocrinol. 1999, 13, 1924-1933. [CrossRef] [PubMed]

139. Xie, D.; Sham, J.S.; Zeng, W.F.; Lin, H.L.; Bi, J.; Che, L.H.; Hu, L.; Zeng, Y.X.; Guan, X.Y. Correlation of aib1 overexpression with advanced clinical stage of human colorectal carcinoma. Hum. Pathol. 2005, 36, 777-783. [CrossRef] [PubMed]

140. Toyoshima, H.; Hunter, T. P27, a novel inhibitor of g1 cyclin-CDK protein kinase activity, is related to p21. Cell 1994, 78, 67-74. [CrossRef]

141. Musat, M.; Korbonits, M.; Pyle, M.; Gueorguiev, M.; Kola, B.; Morris, D.G.; Powell, M.; Dumitrache, C.; Poiana, C.; Grossman, A.B. The expression of the f-box protein skp2 is negatively associated with p27 expression in human pituitary tumors. Pituitary 2002, 5, 235-242. [CrossRef] [PubMed]

142. Zhao, D.; Tomono, Y.; Nose, T. Expression of p27kip1 and ki-67 in pituitary adenomas: An investigation of marker of adenoma invasiveness. Acta Neurochir. 1999, 141, 187-192. [CrossRef] [PubMed]

143. Lloyd, R.V.; Erickson, L.A.; Jin, L.; Kulig, E.; Qian, X.; Cheville, J.C.; Scheithauer, B.W. P27kip1: A multifunctional cyclin-dependent kinase inhibitor with prognostic significance in human cancers. Am. J. Pathol. 1999, 154, 313-323. [CrossRef]

144. Ikeda, H.; Yoshimoto, T.; Shida, N. Molecular analysis of p21 and p27 genes in human pituitary adenomas. Br. J. Cancer 1997, 76, 1119-1123. [CrossRef] [PubMed]

145. Martins, C.S.; Camargo, R.C.; Saggioro, F.P.; Neder, L.; Machado, H.R.; Moreira, A.C.; de Castro, M. P27/CDKN1B translational regulators in pituitary tumorigenesis. Horm. Metab. Res. 2016, 48, 840-846. [CrossRef] [PubMed]

(C) 2017 by the authors. Licensee MDPI, Basel, Switzerland. This article is an open access article distributed under the terms and conditions of the Creative Commons Attribution (CC BY) license (http://creativecommons.org/licenses/by/4.0/). 